\title{
Molecular genetic analysis of podocyte genes in focal segmental glomerulosclerosis-a review
}

\author{
M. M. Löwik • P. J. Groenen • E. N. Levtchenko • \\ L. A. Monnens • L. P. van den Heuvel
}

Received: 8 January 2009/Accepted: 12 June 2009/Published online: 27 June 2009

C) The Author(s) 2009. This article is published with open access at Springerlink.com

\begin{abstract}
This review deals with podocyte proteins that play a significant role in the structure and function of the glomerular filter. Genetic linkage studies has identified several genes involved in the development of nephrotic syndrome and contributed to the understanding of the pathophysiology of glomerular proteinuria and/or focal segmental glomerulosclerosis. Here, we describe already well-characterized genetic diseases due to mutations in nephrin, podocin, CD2AP, alpha-actinin-4, WT1, and laminin $\beta 2$ chain, as well as more recently identified genetic abnormalities in TRPC6, phospholipase C epsilon, and the proteins encoded by the mitochondrial genome. In addition, the role of the proteins which have shown to be important for the structure and functions by gene knockout studies in mice, are also discussed. Furthermore, some rare syndromes with glomerular involvement, in which molecular defects have been recently identified, are briefly
\end{abstract}

M. M. Löwik · L. A. Monnens · L. P. van den Heuvel Department of Paediatric Nephrology,

Radboud University Nijmegen Medical Centre,

Nijmegen, The Netherlands

\section{P. J. Groenen}

Department of Pathology,

Radboud University Nijmegen Medical Centre,

Nijmegen, The Netherlands

E. N. Levtchenko $\cdot$ L. P. van den Heuvel

Department of Paediatric Nephrology,

University Hospital Leuven,

Leuven, Belgium

L. P. van den Heuvel $(\bowtie)$

Laboratory of Pediatrics and Neurology,

P.O. Box 9101, $6500 \mathrm{HB}$,

Nijmegen, The Netherlands

e-mail: B.vandenheuvel@cukz.umcn.nl described. In summary, this review updates the current knowledge of genetic causes of congenital and childhood nephrotic syndrome and provides new insights into mechanisms of glomerular dysfunction.

Keywords Nephrotic syndrome $\cdot$ Focal segmental glomerulosclerosis · Podocytes · Nephrin · Podocin · TRPC6 $\cdot$ PLCE1

\section{The glomerular filtration barrier}

The glomerulus consists of a cluster of capillaries appearing in a looped formation supported by mesangial cells. While blood plasma passes the glomerular capillary loops, the local intracapillary pressure drives plasma through the glomerular filtration barrier which consists of three layers (Fig. 1).

First, the glomerular endothelial cells separate the blood and tissue compartments. The endothelial cells are highly flattened cells and regulate vasomotor tone and hemostasis [4]. The role of the endothelial cells in selective filtration seems not to be substantial since they are highly fenestrated and highly permeable to water and small solutes. However, a recent study has shown that morphological alterations in the endothelial cell glycocalyx, making the cell surface extremely negatively charged, have functional consequences for glomerular permeability [54]. Using the GAGdegrading enzyme chondroitinase decreasing the thickness of the endothelial cell glycocalyx resulted in an increase of albumin clearance [54].

The endothelium is completely surrounded by the second layer, the glomerular basement membrane (GBM). This dense structure of extracellular matrix components provides structural support for the capillary wall necessary 


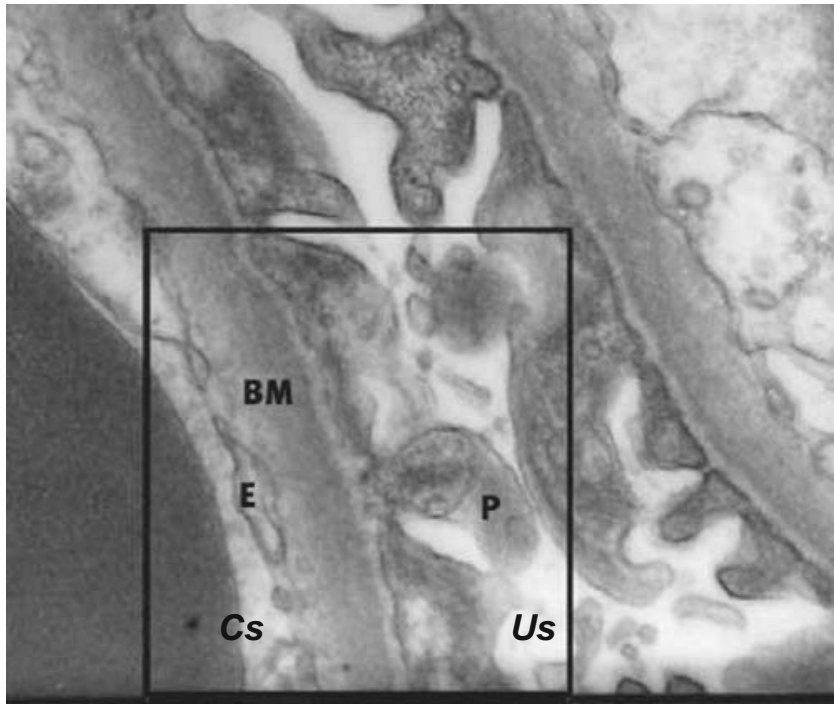

Fig. 1 A cross-section (electron microscopy, original magnification $\times 30,000)$ of the glomerular filtration barrier with the capillary space $(C s)$, urinary space $(U s)$, endothelial cells $(E)$, glomerular basement membrane $(B M)$, and podocytes $(P)$

to maintain local high blood pressure. The main components of the GBM (collagen type IV, laminins, nidogen, and proteoglycans) contribute to the selective permeability of the GBM based on size and charge [72]. In the past years, many studies were focussing on the structure of the GBM because it was considered to be the leading part of the glomerular filtration barrier. Although structural abnormalities in the GBM may lead to proteinuria and hematuria, as it occurs in Alport's syndrome (mainly due to collagen IV $\alpha 5$ chain mutations, but also collagen IV $\alpha 3$ and $\alpha 4$ chains) or Pierson's syndrome (due to laminin $\beta 2$ mutations) [8, 146], the discovery of several novel proteins important for glomerular permeability made the podocytes the favorite candidate for constituting the main part of the glomerular filtration barrier.

The podocytes, or visceral epithelial cells, represent the third layer. They are highly specialized, terminally differentiated cells with cytoplasmic extensions, the so-called foot processes. Podocytes have an important role in size and charge selective permeability, but also in synthesizing and maintaining the GBM [98]. Furthermore, the fenestration of endothelial cells depends most notably on vascular endothelial growth factor A secreted from differentiated podocytes [4].

The foot processes of the podocytes attach to the outer surface of the GBM through cell membrane receptors ( $\alpha 3 \beta 1$ integrins linked to talin, vinculin, and paxillin, and $\alpha$ - and $\beta$-dystroglycans linked to utrophin; see Fig. 2) [68]. Adjacent foot processes interdigitate, forming a pore of about $25-40 \mathrm{~nm}$ in width. This pore, or slit, is covered by a membrane with a "zipper-like" structure [108]. Recently, the structure of the slit membrane became the focus of many studies, and although the complete structure is not elucidated yet, several new proteins were found to be important for its function. Many components of the slit membrane are involved in the pathogenesis of (nephrotic range) proteinuria.

\section{Nephrotic syndrome- focal segmental glomerulosclerosis}

A nephrotic syndrome (NS) is defined by the occurrence of heavy proteinuria, edema, and hypoalbuminemia, and is classified as steroid-sensitive or steroid-resistant. In children NS occurs most commonly at a young age, with a peak incidence at 2 years. In most cases $(\sim 80 \%$, according to the International Study of Kidney Disease in Children (1967-1974), ISKDC) patients have minimal change NS (MCNS), which is characterized by responsiveness to steroid treatment accompanied with more or less frequent relapses. In 5-10\% of NS patients (ISKDC) focal segmental glomerulosclerosis (FSGS) is found [83, 128]. Less frequent histologic lesions are mesangial proliferative glomerulonephritis, membranoproliferative glomerulonephritis, and membranous glomerulopathy [83].

FSGS is a histological finding commonly seen in a large variety of conditions with different underlying causes.

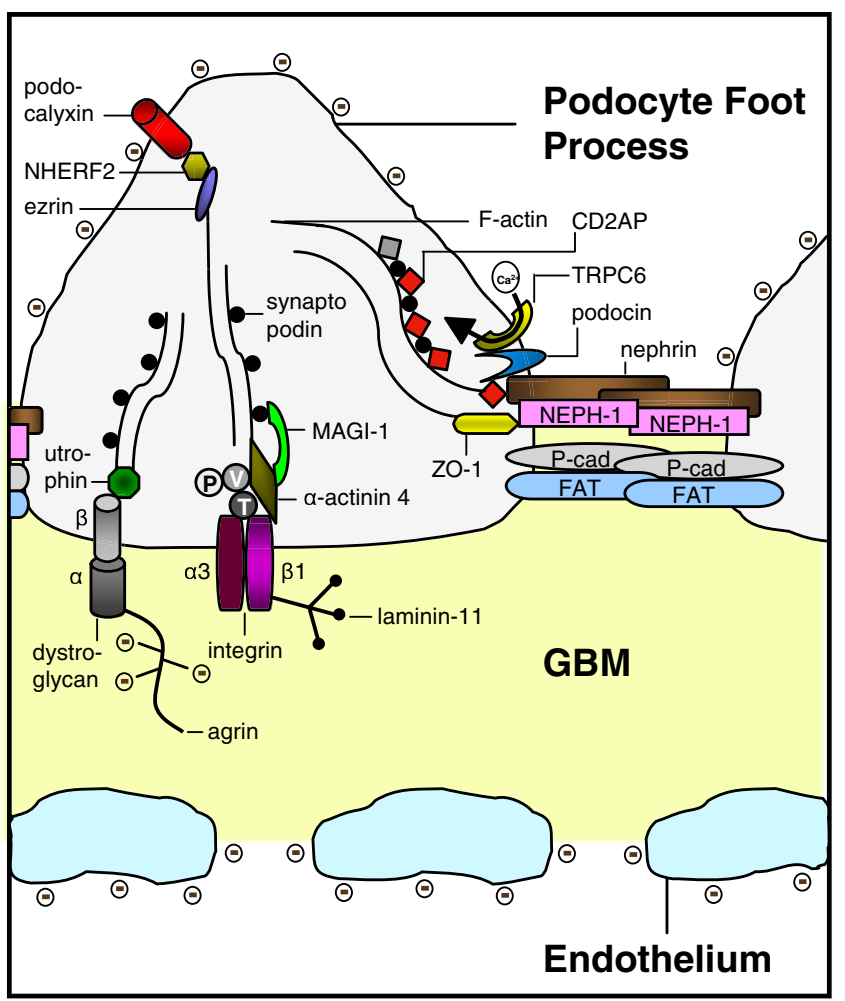

Fig. 2 Molecular anatomy of the podocyte slit membrane, schematic representation. $P$ paxillin, $V$ vinculin, $T$ talin, $\odot$ negatively charged glycogalyx. Modified from [86], with permission 
These conditions share the focal (only some of the glomeruli are involved) segmental (only part of an entire glomerulus is involved) sclerosis of the glomerular capillary tuft and manifests with proteinuria. As the disease progresses, the sclerosis has a more diffuse and global pattern. The biopsy may show mesangial deposits of immunoglobulin $\mathrm{M}$ or complement $\mathrm{C} 3$ and hyaline deposits all over the capillary loops [143]. Podocyte alterations (like foot process effacement) are most notably in FSGS.

Recently, FSGS has been classified in five subcategories: collapsing variant, tip lesion variant, cellular variant, perihilar variant, and FSGS not otherwise specified (NOS) [20, 22 for further reading]. Whether subdividing FSGS in different subcategories gives insight in clinical features and renal outcome is a subject of several reports recently reviewed by D'Agati [21]. Collected data from adult patients with biopsy proven FSGS showed a predisposition of younger and more often African-American patients for the collapsing variant of FSGS [131]. The collapsing and tip variants usually manifest with more severe proteinuria compared to the perihilar and NOS variants. Patients with the last two morphologic variants tend to have higher blood pressure and pathologically more arteriosclerosis [131]. As far as renal outcome concerns, the patients with tip lesion variant of FSGS seem more often to achieve complete remission, whereas the collapsing variant of FSGS has worse renal survival rates [131]. It is not excluded that different morphologic variants represent different stages of disease progression in FSGS.

FSGS commonly progresses to end-stage renal disease (ESRD) requiring dialysis or renal transplantation. Posttransplant recurrence occurs in $35-40 \%$ of patients with idiopathic FSGS [2, 23], mainly a few days after transplantation, and is often sensitive to plasmapheresis and cyclophosphamide $[3,58,116]$ treatment. The recurrence may be due to a circulating plasma factor [116]. This factor may be responsible for an increase in podocyte integrin-linked kinase activity leading to podocyte detachment from the GBM as found in some patients [41]. Recently, cardiotrophin like cytokine-1 has been identified as being a candidate for the FSGS permeability factor [115].

Lately, the role of Notch signaling, which is involved in the regulation of many cellular processes like proliferation, differentiation, and cell death [50], in the development of renal diseases is debated. Although NotchI protein plays a crucial role during kidney development, very little active NotchI can be detected in mature kidneys [134]. In glomerular epithelial cells of patients with diabetic nephropathy or FSGS, however, an increased presence of the active protein domain of NotchI was found, which, based on the homology with mouse podocyte biology [94], may be involved in apoptosis induction.
Another classification of FSGS is based on the underlying cause and subdivides it into three categories: idiopathic, genetic, and secondary due to injury, medication, or drug abuse $[21,143]$. The last years genetic linkage studies have identified several genes involved in the development of FSGS and have contributed to the understanding of its pathophysiology (Table 1). A subset of genes enlisted in Table 1 are discussed below in more detail (Fig. 2).

\section{NPHS1}

One of the major components of the slit membrane is the transmembrane protein nephrin (NPHS1, OMIM 602716). Nephrin has an important role in maintaining the structure of the podocyte slit membrane, as shown by nephrindeficient mice which develop proteinuria and foot process effacement [103]. Injection of anti-nephrin antibody in animals also results in foot process effacement [96]. Intracellularly, nephrin functions as a signaling molecule $[46,47]$. Nephrin (and also CD2AP, another component of the slit membrane) associates with the $\mathrm{p} 85$ regulatory subunit of phosphoinositide 3-OH kinase (PI3K) thereby stimulating the AKT signaling pathway controlling cell growth, migration, and survival [46].

Nephrin oligomers associate with lipid rafts in the slit membrane [126]. A rat model of antibody-induced foot process effacement showed morphological changes of the filtration slits with apical dislocation and tyrosine phosphorylation of nephrin [126]. As such, tyrosine phosphorylation may regulate the subcellular redistribution of slit membrane proteins $[7,126]$. Furthermore, a study in Fyndeficient mice showed an important role for tyrosine phosphorylation in nephrin-dependent intracellular signaling [133]. Fyn, a member of the Src protein kinase family, tyrosine phosphorylates the cytoplasmic domain of nephrin and Fyn-deficient mice develop proteinuria and foot process effacement [133].

NPHS1 was found mutated in patients with the congenital nephrotic syndrome of the Finnish type (CNF, OMIM 256300). CNF has an incidence of 1:10,000 births in Finland, but less frequently in other countries. Although several missense mutations were found in CNF patients, two mutations, the Fin $_{\text {major }}$ (deletion nucleotides 121 and 122) and $\mathrm{Fin}_{\text {minor }}$ (premature stop at amino acid 1109), account for over $90 \%$ of the cases in Finland [59]. Recurrence of CNF may occur in $20-25 \%$ of the patients after receiving a renal allograft and may be caused by antinephrin antibodies [97, 137]. In addition to the renal disease, patients with NPHS1 mutations may also show neurological symptoms including muscular hypotonia, dyskinesia, mild cerebral atrophy, and hearing impairment of still obscure origin [70]. 
Table 1 Characteristics of hereditary diseases involved in nephrotic syndrome

\begin{tabular}{|c|c|c|c|c|c|c|}
\hline $\begin{array}{l}\text { List of } \\
\text { diseases }\end{array}$ & $\begin{array}{l}\text { Mode of } \\
\text { inheritance }\end{array}$ & Protein & $\begin{array}{l}\text { Protein } \\
\text { function }\end{array}$ & Gene & Chrom. & $\begin{array}{l}\text { Protein } \\
\text { expression slit } \\
\text { membrane }\end{array}$ \\
\hline $\begin{array}{l}\text { Congenital nephrotic } \\
\text { syndrome of the } \\
\text { Finnish type }(\mathrm{CNF})\end{array}$ & $\begin{array}{r}\text { Autosomal } \\
\text { recessive }\end{array}$ & Nephrin & $\begin{array}{l}\text { Key component of the } \\
\text { podocyte slit } \\
\text { diaphragm }\end{array}$ & NPHS1 & $19 \mathrm{q} 13.1$ & $\begin{array}{l}\text { Podocyte slit } \\
\text { membrane }\end{array}$ \\
\hline $\begin{array}{l}\text { Steroid-resistant } \\
\text { nephrotic syndrome } \\
\text { (SRN1) }\end{array}$ & $\begin{array}{r}\text { Autosomal } \\
\text { recessive }\end{array}$ & Podocin & $\begin{array}{l}\text { Establishment of the } \\
\text { podocyte slit } \\
\text { diaphragm }\end{array}$ & NPHS2 & $1 \mathrm{q} 25-\mathrm{q} 31$ & $\begin{array}{l}\text { Podocyte slit } \\
\text { membrane }\end{array}$ \\
\hline Familial FSGS & $\begin{array}{r}\text { Autosomal } \\
\text { recessive }\end{array}$ & $\begin{array}{l}\mathrm{CD} 2 \text {-associated } \\
\text { protein }\end{array}$ & $\begin{array}{l}\text { Cytoskeletal } \\
\text { remodeling, cell } \\
\text { motility, endocytosis }\end{array}$ & $C D 2 A P$ & 6 & $\begin{array}{l}\text { Podocyte slit } \\
\text { membrane }\end{array}$ \\
\hline $\begin{array}{l}\text { Familial focal } \\
\text { segmental } \\
\text { glomerulosclerosis } \\
\text { (FSGS1) }\end{array}$ & $\begin{array}{r}\text { Autosomal } \\
\text { dominant }\end{array}$ & Alpha-actinin-4 & Anchoring protein & ACTN4 & $19 \mathrm{q} 13$ & $\begin{array}{l}\text { Predominantly } \\
\text { podocyte cell body }\end{array}$ \\
\hline $\begin{array}{l}\text { Denys-Drash } \\
\text { syndrome (DDS)/ } \\
\text { Frasier syndrome } \\
\text { (FS) }\end{array}$ & $\begin{array}{l}\text { de novo } \\
\quad \text { (dominant) }\end{array}$ & Wilms tumor 1 & Transcription factor & $W T 1$ & $11 \mathrm{p} 13$ & $\begin{array}{l}\text { Nucleus and } \\
\text { cytoplasm of } \\
\text { podocyte cell body }\end{array}$ \\
\hline $\begin{array}{l}\text { Familial focal } \\
\text { segmental } \\
\text { glomerulosclerosis } \\
\text { (FSGS2) }\end{array}$ & $\begin{array}{r}\text { Autosomal } \\
\text { dominant }\end{array}$ & $\begin{array}{l}\text { Transient receptor } \\
\text { potential cation } \\
\text { channel } 6\end{array}$ & $\begin{array}{l}\mathrm{Ca}^{2+} \text { entry during cell } \\
\text { proliferation }\end{array}$ & TRPC6 & $11 q 21-q 22$ & $\begin{array}{l}\text { Tubules, podocytes, } \\
\text { mesangial and } \\
\text { endothelial cells }\end{array}$ \\
\hline $\begin{array}{l}\text { Early-onset familial } \\
\text { nephrotic syndrome }\end{array}$ & $\begin{array}{r}\text { Autosomal } \\
\text { recessive }\end{array}$ & $\begin{array}{l}\text { Phospholipase C } \\
\text { epsilon }\end{array}$ & $\begin{array}{l}\text { Involved in cell } \\
\text { growth and } \\
\text { differentiation, gene } \\
\text { expression }\end{array}$ & PLCE1 & $10 \mathrm{q} 23$ & $\begin{array}{l}\text { Cytoplasm podocyte } \\
\text { cell body }\end{array}$ \\
\hline Pierson's syndrome & $\begin{array}{l}\text { Autosomal } \\
\text { recessive }\end{array}$ & Laminin $\beta 2$ chain & $\begin{array}{l}\text { Establishment of the } \\
\text { glomerular basement } \\
\text { membrane }\end{array}$ & $L A M B 2$ & $3 \mathrm{p} 21$ & $\begin{array}{l}\text { Glomerular basement } \\
\text { membrane }\end{array}$ \\
\hline $\begin{array}{l}\text { Mitochondrial } \\
\text { disorder }\end{array}$ & Maternal & Non-protein tRNA & Amino acid supply & NA & mtDNA & $\begin{array}{l}\text { Mitochondrion } \\
\text { renal cells }\end{array}$ \\
\hline CoQ10 deficiency & $\begin{array}{l}\text { Autosomal } \\
\text { recessive }\end{array}$ & $\begin{array}{l}\text { Parahydroxy- } \\
\text { benzoate- } \\
\text { polyprenyl- } \\
\text { transferase }\end{array}$ & $\begin{array}{l}\text { Electron carrier in } \\
\text { mitochondrial } \\
\text { respiratory chain }\end{array}$ & COQ2 & $4 q 21.23$ & $\begin{array}{l}\text { Mitochondrion } \\
\text { renal cells }\end{array}$ \\
\hline Nail-patella syndrome & $\begin{array}{l}\text { de novo } \\
\text { (dominant) }\end{array}$ & $\begin{array}{l}\text { LIM homeobox } \\
\text { transcription factor } \\
1 \text { beta }\end{array}$ & Transcription factor & $L M X 1 B$ & $17 \mathrm{q} 11$ & $\begin{array}{l}\text { Nucleus and } \\
\text { cytoplasm of } \\
\text { podocyte cell body }\end{array}$ \\
\hline $\begin{array}{l}\text { Schimke immuno- } \\
\text { osseous dysplasia }\end{array}$ & $\begin{array}{r}\text { Autosomal } \\
\text { recessive }\end{array}$ & $\begin{array}{l}\text { SWI/SNF2-related, } \\
\text { matrix-associated, } \\
\text { actin-dependent } \\
\text { regulator of } \\
\text { chromatin, } \\
\text { subfamily a-like } 1\end{array}$ & $\begin{array}{l}\text { Gene regulation, } \\
\text { replication, } \\
\text { recombination, and } \\
\text { DNA repair }\end{array}$ & SMARCAL1 & $2 q 34-q 36$ & $\begin{array}{l}\text { Nucleus of podocyte } \\
\text { cells and proximal } \\
\text { tubule }\end{array}$ \\
\hline $\begin{array}{l}\text { Mandibuloacral } \\
\text { dysplasia }\end{array}$ & $\begin{array}{r}\text { Autosomal } \\
\text { recessive }\end{array}$ & $\begin{array}{l}\text { Zinc metallo- } \\
\text { proteinase } \\
\text { STE24 }\end{array}$ & $\begin{array}{l}\text { Potentially involved in } \\
\text { processing of } \\
\text { farnessylated protein }\end{array}$ & ZMPSTE24 & $1 \mathrm{p} 34$ & Unknown \\
\hline $\begin{array}{l}\text { Galloway-Mowat } \\
\text { syndrome }\end{array}$ & $\begin{array}{r}\text { Autosomal } \\
\text { recessive }\end{array}$ & GMS1 & unknown & GMS1 & Unknown & Podocytes \\
\hline Fechtner syndrome & $\begin{array}{r}\text { Autosomal } \\
\text { dominant }\end{array}$ & $\begin{array}{l}\text { Nonmuscle } \\
\text { myosinllA } \\
\text { heavy chain }\end{array}$ & Actin-based motility & МYH9 & $22 q 12.3$ & $\begin{array}{l}\text { Tubular epithelia, } \\
\text { mesangial cells and } \\
\text { podocyte }\end{array}$ \\
\hline $\begin{array}{l}\text { Action myoclonus- } \\
\text { renal failure } \\
\text { syndrome }\end{array}$ & $\begin{array}{r}\text { Autosomal } \\
\text { recessive }\end{array}$ & $\begin{array}{l}\text { Lysosomal integral } \\
\text { membrane protein } \\
\text { type } 2\end{array}$ & $\begin{array}{l}\text { Lysosomal degradation } \\
\text { of macromolecules, } \\
\text { RNA and DNA }\end{array}$ & $S C A R B 2$ & $4 q 13-21$ & $\begin{array}{l}\text { Lysosomal membrane } \\
\text { of glomerular cells } \\
\text { (study in mice) }\end{array}$ \\
\hline
\end{tabular}

Chrom. chromosome, $N A$ not applicable, $m t D N A$ mitochondrial DNA, GBM glomerular basement membrane, $F P$ foot process, $N S$ nephrotic syndrome, ESRD end-stage renal disease, FSGS focal segmental glomerulosclerosis, DMS diffuse mesangial sclerosis 


\section{NPHS2}

Podocin (NPHS2, OMIM 604766), a member of the stomatin protein family, is exclusively expressed in the podocytes and localizes at the insertion of the slit membrane. Due to its similarity to stomatin, it is believed that podocin forms a hairpin-like structure with intracellular $\mathrm{NH}_{2}$ - and $\mathrm{COOH}$-termini [13, 109].

Podocin, like nephrin, associates with lipid rafts [121], and recruits nephrin and CD2AP in these rafts ensuring a stable and proper functioning filtration barrier. The $\mathrm{COOH}-$ terminal cytoplasmic tail of podocin interacts with nephrin and Cd2ap (the mouse homolog) [121]. This protein interaction greatly enhances nephrin-induced signaling in vitro [47]. The $\mathrm{COOH}$-terminal domain of podocin also binds NEPH-1, a podocyte slit membrane protein structurally related to nephrin [122]. NEPH-1 is involved in maintaining the structure of the filtration barrier and also interacts with nephrin [75].

Podocin dysfunction leads to alterations of the slit membrane assembly and to proteinuria in experimental models. NPHS2 ${ }^{-1-}$ mice develop proteinuria and massive mesangial sclerosis (different from FSGS seen in humans), the podocytes are enlarged and focally vacuolized. The sclerosis rapidly progresses with age. Beside the absence of podocin, no nephrin is found in the foot processes as well. The podocin-deficient mice die a few days after birth [110].

In human, NPHS2 mutations, are mainly associated with autosomal recessive steroid-resistant nephrotic syndrome (SRN1, OMIM 600995) [70], but were also found in sporadic cases of steroid-resistant nephrotic syndrome patients $[16,57,67,132]$. A recent study has demonstrated that also milder NPHS1 mutations can cause a childhoodonset steroid-resistant nephrotic syndrome with underlying histological lesions ranging from minimal change nephropathy to FSGS [101].

The podocin variant $\mathrm{R} 229 \mathrm{Q}$ is often found and has an allele frequency of $3.6 \%$ in a control population. The mutant protein has a decreased binding efficiency to nephrin and enhances FSGS susceptibility in association with a second NPHS2 mutation [132]. The R229Q variant is also associated with microalbuminuria in the general population [100].

Mutated podocin may cause a disturbance in recruiting nephrin to the plasma membrane $[49,111]$, which is comparable with the lack of nephrin in the slit membrane found in podocin-deficient mice [110]. The R138Q NPHS2 mutant (one of the most common found mutation) results in retainment of the mutant podocin in the endoplasmatic reticulum. The R138X NPHS2 mutant yields a mutant podocin protein that is not able to associate with lipid rafts in the plasma membrane. Both mutant proteins were unable to recruit nephrin to the lipid rafts and lost their ability to enhance nephrin signaling $[49,111] . \mathrm{NH}_{2}$-terminal mutant proteins were still able to associate with lipid rafts and had no effect on nephrin localization [95]. Collected clinical data from patients with NPHS2 mutations showed that podocin mutants retained in the endoplasmatic reticulum are associated with earlier onset of the disease than those correctly targeted to the cell membrane [111].

Early reports showed that patients with NPHS2 mutations had no recurrence of FSGS after renal transplantation. Now it is believed that patients with NPHS2 mutations have a lower risk for recurrent FSGS after renal transplantation compared to patients with idiopathic FSGS [10, 112, 139]. Patients carrying a heterozygous NPHS2 mutation show a higher risk for recurrent FSGS (five out of eight published) in contrast to patients with homozygous or compound heterozygous mutations (five out of 68 published) [17]. The authors state that grafts from carriers of NPHS2 mutations, such as from parents, should be avoided because of the higher risk of recurrent FSGS. Furthermore, carriers of heterozygous NPHS2 mutations should be strictly monitored in the post-graft phase [17].

\section{CD2AP}

Although first found in a yeast two-hybrid screen as a protein binding to the T-cell membrane protein $\mathrm{CD} 2$ during cell-cell interaction [28], an important role for Cd2ap (CD2-associated protein) in the kidney became evident when Cd2ap knockout mice died because of renal failure involving the glomerulus [125]. The $\mathrm{Cd} 2 \mathrm{ap}^{-/-}$mice died at an age of 6 to 7 weeks, but already at 1 week glomeruli were increased in size and cellularity (mesangial cell proliferation and glomerulosclerosis) and electron microscopy showed extensive foot processes effacement [125]. $\mathrm{Cd} 2 \mathrm{ap}^{+/-}$mice showed no proteinuria, but have an increased susceptibility to glomerular injury by immune complexes and nephrotoxic antibodies [60]. At 9 months of age, glomerular lesions were present with an increase in mesangial cellularity. Some lesions were similar to human FSGS and for this reason primary FSGS patients were tested for mutations in the CD2AP gene (the human homolog of $\mathrm{Cd} 2 \mathrm{ap}$, originally named CMS, OMIM 604241) [60] One heterozygous splice-site mutation was detected in two patients. The predicted mutated protein would lack more than $80 \%$ of the protein. Immunoblotting $\mathrm{CD} 2 \mathrm{AP}$ isolated from immortalized B-lymphocytes showed a reduction in CD2AP expression in these patients [60]. Beside the heterozygous splice-site mutation one homozygous $C D 2 A P$ mutation has been described [77]. This mutation results in a premature stop codon and a protein truncation of $4 \%$ at the COOH-terminus. No CD2AP protein was found in the patients' lymphocytes. Both 
parents, who are heterozygous for the mutation, show no kidney pathology and no decrease in CD2AP expression in lymphocytes. These two different reports show that not all heterozygous $C D 2 A P$ mutations cause kidney disease. The development of FSGS clearly depends on the severity of the mutation [77].

$\mathrm{CD} 2 \mathrm{AP} / \mathrm{Cd} 2 \mathrm{ap}$ is a multifunctional adaptor molecule localized to the cytoplasm, membrane ruffles, and leading edges of cells [61]. The protein plays a role in cytoskeletal remodeling $[28,61]$, cell survival $[46,118]$, and endocytosis $[19,63,80]$. The $\mathrm{COOH}$-terminus of CD2AP directly interacts with the cytoskeletal protein filamentous actin (F-actin) [61, 71] and synaptopodin, an actin-bundling protein [48]. At the slit membrane, CD2AP interacts with nephrin and podocin $[121,124]$ and serves as a linker anchoring slit membrane proteins to the actin cytoskeleton of podocytes.

CD2AP and nephrin bind to the p85 regulatory subunit of phosphoinositide 3-OH kinase (PI3K) stimulating the serine-threonine kinase AKT [46]. One of the target proteins of AKT is Bad, a proapoptotic $\mathrm{Bcl} 2$ family member that interacts with prosurvival $\mathrm{Bcl} 2$ family members to promote apoptosis. Phosphorylated Bad is inactive and protects podocytes against detachment-induced cell death [46].

Combined mutations in two podocyte genes may be a common etiology for glomerular disease [48]. Crossbreeding heterozygous $\mathrm{Cd} 2$ ap knockout mice with mice heterozygous (knockout) for synaptopodin or Fyn, which alone did not result in clinical kidney pathology, resulted in spontaneous proteinuria and FSGS-like glomerular damage supporting a role for CD2AP haploinsufficiency [60]. A role of combined mutations in the development of glomerular disease is also seen in a patient group with non-familial childhood-onset FSGS. One patient showed a $C D 2 A P$ mutation combined with a heterozygous NPHS2 mutation [76].

\section{ACTN4}

Alpha-actinin-4 (ACTN4, OMIM 604638) is an actinbundling protein important for the integrity of the podocyte cytoskeleton associated with cell motility. Transgenic ACTN4 mice develop a severe glomerular disease and FSGS [66, 86]. Lymphocytes of homozygous ACTN4deficient mice displayed an increase in lymphocyte chemotaxis, supporting the role of ACTN4 in cell motility [66]. Podocyte cell lines derived from these ACTN4-deficient mice show less adherence to the GBM components collagen IV and laminins-10 and laminins-11, also indicating its role in maintaining glomerular architecture and preventing disease [24].
ACTN4 is highly expressed in several human tissues. Despite the overall expression of ACTN4, the human phenotype associated with $A C T N 4$ mutations only manifests in the kidney. Mutations in ACTN4 are associated with an autosomal dominant form of familial FSGS (OMIM 603278). By now, only three ACTN4 missense mutations have been described in literature $[55,140]$. The mutated ACTN4 proteins showed a higher binding affinity to Factin, and may change the mechanical characteristics of the podocyte [55]. In vitro studies in podocytes of mice homozygous for the human disease-causing K225E substitution, shows aggregation of the mutant $\alpha$-actinin- 4 with Factin. Furthermore, the conformational change also leads to an increase of the actin-binding stoichiometry and a resistance to regulation by $\mathrm{Ca}^{2+}$ [141]. In sporadic cases of FSGS, without an apparent familial disease pattern, ACTN4 amino acid substitutions were also found [140]. However, cellular localization of the mutated proteins and actin-binding assays show that these mutations are probably not disease-causing or contributing to the disease [140].

\section{WT1}

Another well-described genetic defect in patients with primary nephrotic syndrome is the spectrum of clinical pictures caused by mutations in WT1 (for review 74, 90, 135, OMIM 607102), a transcription factor regulating several programs of cellular proliferation and differentiation. The WT1 gene is positionally cloned based on its role in the development of Wilms tumors (OMIM 194070), the most common form of cancer in children [33, 38]. Heterozygous de novo mutations in WT1 cause Denys-Drash syndrome (DDS, OMIM 194080) and Frasier syndrome (FS, OMIM 136680), two overlapping syndromes [84], characterized by nephrotic syndrome with either diffuse mesangial sclerosis (DMS in DDS) or FSGS (in FS), genitourinary defects, and a higher risk of developing Wilms tumor (in DDS) or gonadal dysgerminoma (in both DDS and FS).

WT1 has a transcription-regulating domain (encoded by exons 1 to 6 ) and a DNA-binding zinc finger domain (encoded by exons 7 to 10). There are four major isoforms due to the insertion of the amino acids KTS between zinc fingers 3 and 4 (alternative splice site directly situated after exon 9), and due to the insertion of 17 amino acids completely encoded by exon 5 . The insertion/deletion of KTS influences the space between zinc fingers 3 and 4 and thereby the binding properties of the protein [39].

The mutations found in DDS patients, but also in cases of isolated DMS, are mostly missense mutations (80\%) in zinc fingers 2 and 3 (exon 8 and 9). The R394W (1180 $\mathrm{C}>\mathrm{T}$, exon 9) substitution is most frequently found in almost $50 \%$ of the DDS patients $[14,74,99]$. These 
mutations affect the DNA-binding stability of WT1 to the target gene [73]. FS patients usually present with intron 9 splice-site mutations affecting the +KTS/-KTS ratio [6, 62]. The fact that DDS and FS are overlapping syndromes is strengthened by the finding of intron 9 splice-site mutations in patients with a phenotype of DDS [25, 39, 53, 84], and an exon 9 mutation in a patient with FS [64].

\section{TRPC6}

Transient receptor potential cation channel subfamily C, 1-7 (TRPC) is a subgroup of the TRP family of cation channels involved in the regulation of $\mathrm{Ca}^{2+}$ influx. These ion channels can be activated subsequent to either depletion of $\mathrm{Ca}^{2+}$ from internal stores or through receptor-mediated processes [107]. TRPC channels are expressed in many tissues. In the podocytes TRPC-1, TRPC-2, TRPC-5, and TRPC-6 are expressed [106]. TRPC6 (OMIM 603652) is localized to the podocyte cell body, primary processes and in close vicinity to the slit membrane were it interacts with nephrin and podocin (not CD2AP) [106]. TRPC6 is also abundantly expressed in mesangial cells [127]. In diabetic nephropathy, the mesangial contractile function is impaired, most probably due to a reduced $\mathrm{Ca}^{2+}$ influx. A recent study showed that high glucose downregulates the TRPC6 protein which might contribute to the impaired $\mathrm{Ca}^{2+}$ signaling of mesangial cells seen in diabetes [36].

TRPC6 was found mutated in families with an autosomal dominant form of FSGS (OMIM 603965) [106, 142]. These mutations may cause a gain of function. The P112Q mutated TRPC6 protein showed an enhanced influx of $\mathrm{Ca}^{2+}$, especially after activation of the G-protein-coupled receptor AT1 by angiotensin II, and the cellular localization of the mutant protein is more situated at the plasma membrane [142]. An increase in $\mathrm{Ca}^{2+}$ influx is also seen in two other missense mutations (R895C and E897K), but absent in three different ones (N143S, S270T, and K874X) [106]. In these cases an altered channel regulation or an altered interaction with other slit membrane proteins (like nephrin and podocin) may cause the disease [106]. In addition to the effects of gain-of-function mutations in the TRPC6 gene, also elevated levels of wild-type TRPC6 protein in some acquired glomerular diseases (like membranous nephropathy and puromycin aminonucleoside-induced albuminuria) may lead to podocyte dysfunction [88]. The pathways that TRPC6 may modulate are discussed in a recent seminar [119].

\section{PLCE1}

PLCE1 (phospholipase C epsilon, OMIM 608414) belongs to the phospholipase C (PLC) family involved in intracel- lular signaling, necessary for cell growth and differentiation. PLC plays an important role in regulating the $\mathrm{Ca}^{2+}$ release from internal stores as well as the influx of $\mathrm{Ca}^{2+}$ through cation channels (like TRPC). PLC is activated by binding of a hormone or growth factor to its receptor and PLC in turn converts phosphatidylinositol-4,5-bisphosphate into inositol 1,4,5-trisphosphate (IP3) and diacylglycerol. Plasma membrane channels are activated and cations flow into the cell [31].

In the kidney, PLCE1 expression is found in the podocyte cell body and foot processes [43]. PLCE1 expression appears at the S-shaped stage of glomerular development and is highly expressed during the early capillary loop stage [43]. Recently, positional cloning identified the PLCE1 gene being involved in families with early-onset NS and ESRD (OMIM 610725) [43]. Renal histopathology generally shows DMS and histochemistry reveals reduced nephrin expression. In two patients (carrying the nontruncating missense mutation S1484L) biopsies revealed FSGS. In these patients the age of onset was relatively late as was the age of reaching ESRD [43]. A recent study in patients with isolated (non-syndromic) DMS, showed that PLCE1 truncating mutations are more frequently found than mutations in WT1 or $L A M B 2$, two genes known to cause isolated DMS as well [32]. The authors speculate that missense mutations in PLCE1 may be associated with a milder disease course in isolated DMS or other histologic variants such as FSGS $[32,43]$.

A zebrafish knockdown model was used to investigate the role of PLCE1 in the maintenance of the podocyte filtration barrier during development. The zebrafish PLCE1 ortholog was knocked-down in embryo's using antisense morpholino oligonucleotides and barrier function was assayed at 4-dayold embryos by vascular retention of a large FITC-labeled tracer molecule. In control embryos, the tracer molecule retained in the vasculature. Morpholino-injected embryos showed abundant FITC-positive endocytic vesicles in the pronephric tubule, distal to the glomerulus. This indicated a breakdown of the barrier function in the pronephric glomerulus [43].

\section{Laminin $\beta-2$}

The heterotrimeric laminin is assembled by three polypeptide chains: $\alpha, \beta$, and $\gamma$. Different isoforms have been identified. Laminin-11 $(\alpha 5 \beta 2 \gamma 1)$ is predominantly found in the adult GBM and replaces the laminin-1 ( $\alpha 1 \beta 1 \gamma 1)$ isoform, initially expressed during kidney development [129].

Mutations in the $L A M B 2$ gene, encoding the laminin $\beta 2$ chain (OMIM 150325), are associated with the Pierson's syndrome (OMIM 609049). This syndrome is characterized by early-onset nephrotic syndrome with DMS rapidly 
progressing to ESRD and distinct ocular abnormalities (in particular microcoria) [146]. The $L A M B 2$ mutations result in loss of laminin- $\beta 2$ expression in the kidney and other tissues studied [146]. Mutations were also found in patients with congenital nephrotic syndrome (and FSGS) with or without minor ocular changes [40]. These results indicate genotype-phenotype correlations among patients with $L A M B 2$ mutations. The authors speculated that complete loss-of-function (e.g. truncating) mutations appear to be associated with the complete Pierson syndrome, whereas missense mutations may display variable phenotypes ranging from a milder variant of Pierson's syndrome to isolated congenital nephrotic syndrome with or without minor ocular abnormalities [40]. The frequency of hematuria in these patients is not clear from the clinical data.

\section{Mitochondrial disorders}

Mitochondrial cytopathies, either caused by mutations in the maternally inherited mitochondrial DNA (mtDNA) or in nuclear DNA, represent a heterogeneous group of multisystem disorders [120]. Mitochondria are non-uniformly distributed in tissues and mutated and wild-type mtDNA coexist in cells (heteroplasmy). These characteristics contribute to the large variety of clinical symptoms seen in mtDNA mutations [120].

Mutations in the tRNA ${ }^{\text {Leu(UUR) }}$ (OMIM 590050) gene are mainly associated with the MELAS syndrome (mitochondrial myopathy, encephalopathy, lactic acidosis, and stroke-like episodes, OMIM 540000) [102]. The most common transition $\mathrm{A} 3243 \mathrm{G}$ is also found in patients with FSGS sometimes associated with maternally inherited diabetes and/or sensorineural hearing loss [18, 27, 37, $44,52,69,92,144]$. In most patients proteinuria is below nephrotic range and the FSGS progresses slowly.

The effect of the A3243G mutation to the function of the tRNA $^{\text {Leu }}$ has been studied [145]. A3243G mutant tRNA ${ }^{\text {Leu }}$ have a shorter life span and the extent of aminoacylation ("charging" of a tRNA with an amino acid) was rather low (less than 30\%) compared to wildtype [145].

Mutations were also found in other mitochondrial tRNA genes. In one patient, a A5843G transition was found in the tRNA $^{\text {Tyr }}$ (OMIM 590100) gene. The patient presented with mitochondrial cytopathy preceded by steroid-resistant FSGS. A skeletal muscle biopsy showed a combined respiratory chain deficiency and a partial deficiency of coenzyme Q10 most probably secondary to the oxidative damage [117]. Finally, the A4269G substitution in the tRNA $^{\text {Ile }}$ gene (OMIM 590045) is described in a patient with mitochondrial encephalomyopathy and multi-organ disorders including deafness, epilepsy, FSGS, and dilated myopathy later in life [130].
Coenzyme Q10 (CoQ10) plays an important role in the electron transport from complex I and II to complex III of the mitochondrial respiratory chain. Coenzyme CoQ10 deficiency (OMIM 607426) is associated with a variety of clinical phenotypes. Recently, a mutation in the nuclear DNA was found in a patient with CoQ10 deficiency [104]. This patient presented at age 12 months with proteinuria due to FSGS, mild psychomotor delay, and optic atrophy. Homozygosity mapping revealed a homozygous mutation in the COQ2 gene, encoding para-hydroxybenzoatepolyprenyl-transferase (OMIM 609825), an enzyme involved in the CoQ10 biosynthetic pathway [104]. The pathogenity of the mutation was demonstrated by complementation experiments in COQ2-deficient yeast and showed full functional complementation after transformation with wild-type COQ2 but not mutant COQ2 [78]. This genetic defect of the respiratory chain, is related to lateonset nephrotic syndrome with multiple organ involvement. However, respiratory chain deficiency has also been reported in one infant with congenital nephrotic syndrome characterized by diffuse mesangial hypercellularity and focal tubular dilation [35] and in one infant with glomerular lesions characterized by crescentic glomerulonephritis [26]. The encephalopathy in patients with primary CoQ10 deficiency may be improved by oral CoQ10 supplementation. Recently, it is shown that early administration of CoQ10 may also result in progressive recovery of the renal function and reduction of proteinuria [89].

\section{Other rare cases of hereditary FSGS and recent findings}

The nail-patella syndrome (OMIM 161200) is a rare autosomal dominant disorder characterized by dysplasia of the nails, absent or malformed patellas, dysplasia of the elbows and frequently glaucoma and progressive nephropathy. Renal biopsies reveal non-specific findings mostly related to the degree of renal failure, including FSGS, proliferative glomerulonephritis with crescent formation, and hyalinization of the glomeruli [12]. The gene involved is the transcription factor $L M X 1 B$ (OMIM 602575) which, among others, is required for expression of CD2AP protein and podocin [87].

Mutations in SMARCAL1 (OMIM 606622) are involved in the development of Schimke immuno-osseous dysplasia (OMIM 242900). This autosomal recessive disorder is characterized by spondyloepiphyseal dysplasia causing growth retardation, defective cellular immunity, hyperpigmented macules, dysmorphic facial feature, and nephrotic syndrome (due to FSGS). SMARCAL1 encodes an actin-dependent regulator of chromatin which is involved in gene regulation, replication, recombination, and DNA repair [11]. More detailed studies of its role are 
provided by Elizondo et al. [29]. Recently, mutations in SMARCAL1 were also found in two siblings with an incomplete phenotype of Schimke immuno-osseous dysplasia. The siblings were initially classified as suffering from familial steroid-resistant nephrotic syndrome. In prepuberty they had proportionate short stature which developed into disproportions during adolescence. No other syndrome-specific symptoms were found. Milder phenotypes may be clinically overlooked [147]. It has been demonstrated that anthropometric measures are helpful to distinguish Schimke immuno-osseous dysplasia from other forms of chronic kidney disease [79].

In three patients (of two families) a nonsense mutation in tetraspanin CD151 (OMIM 602243) causes end-stage familial nephropathy with pretibial epidermolysis bullosa and sensorineural deafness (OMIM 609057). The only available renal biopsy of one patient did not show FSGS but splitting of the tubular basement membrane and thickening and fragmentation of the GBM [56]. CD151 null mice, however, develop massive proteinuria while aging caused by FSGS [113].

Mandibuloacral dysplasia (MAD, OMIM 248370/ 608612) is a rare autosomal recessive syndrome with variable clinical features. These features include mandibular and clavicular hypoplasia, acro-osteolysis of terminal phalanges, delayed closure of cranial sutures, joint contractures, mottled pigmentation, and lipodystrophy. MAD is also genetically heterogeneous: two loci have been identified. So far, most mutations were found in $L M N A$, encoding lamin A (OMIM 150330), a structural protein component of the nuclear lamina determining nuclear shape and size [51]. Only three patients have been reported with compound heterozygous mutations in ZMPSTE24 (OMIM 606480). This gene encodes a zinc metallo-proteinase involved in post-translational processing of prelamin A. Two of them presented with renal failure caused by FSGS, suggesting FSGS as a phenotypic manifestation in patients with ZMPSTE24 deficiency [1].

The Galloway-Mowat syndrome (GMS, OMIM 138770) is an autosomal recessive disorder characterized by microcephaly, severe mental retardation, hiatal hernia, and steroidresistant nephrotic syndrome. In GMS, the nephrotic syndrome occurs in the first 4 months of life, is steroidresistant and rapidly progresses to end-stage renal disease. Histology shows heterogeneous lesions: minimal changes, endocapillary proliferation, FSGS (in most cases), and, in end stages, DMS [114]. Recent linkage studies in two Algerian families identified a homozygous mutation in the GMS1 gene. The protein encoded by this gene is expressed in many tissues, including brain and glomerular podocytes, and has yet an unknown function [148].

Recently, MYH9 and SCARB2 have been identified as being involved in the development of FSGS. MYH9 encodes for the heavy chain of nonmuscle myosinIIA (NMMHC-IIA, OMIM 160775). Myosins of class II are widely distributed in most tissues and are essential components of the cell motor system involved in several important cell functions. These, among others, include phagocytosis, maintenance of cell shape and polarity, and intracellular organelle/particle trafficking [81]. Nonmuscle myosinII is composed of two heavy chains and two pairs of light chains. The $\mathrm{NH}_{2}$-terminal region contains an actin and ATP-binding domain required for motor activity. The $\mathrm{COOH}$-terminus allows the molecules to form filaments [123]. In the kidney, NMMHC-IIA is localized in the tubular epithelia and in the glomeruli it is expressed in podocytes and mesangial cells [34].

Heterozygous mutations of MYH9 are involved in a complex disorder named MYH9-related disease characterized by platelet macrocytosis, thrombocytopenia, and leukocyte inclusions containing NMMHC-IIA. Complications that may arise are deafness, cataracts, and renal failure. In the past, these patients were classified as being affected by May-Hegglin anomaly, Sebastian syndrome, Fechtner syndrome, or Epstein syndrome (OMIM 155100, 605249 , 153640, and 153650, respectively). It is now believed that these disorders are not distinct entities, but rather a single illness with a continuous clinical spectrum [81]. In a large family with Fechtner syndrome, ten members carried a $M Y H 9$ missense mutation. Only two members had renal problems. Electron microscopy showed FSGS and segmental effacement of podocytes in these patients [34]. Why the other family members did not develop renal problems remains unclear. Most probably other additional factors play a role [34, 65]. More recently, MYH9 was suggested to be a risk gene for the development of idiopathic FSGS by usage of a genome scan on AfricanAmerican individuals with FSGS. However, sequencing of the 40 exons and intron-exon junctions of MYH9 did not reveal any causal sequence variation. The authors hypothesize that the variation may occur in regulatory elements or splice-site determinants influencing RNA expression or protein structure [65]. Future studies are necessary to identify the precise role of MYH9 in the development of FSGS.

Action myoclonus-renal failure (AMRF, OMIM 254900) syndrome is a lethal inherited form of progressive myoclonus epilepsy associated with renal failure due to FSGS. It usually starts at 15-25 years of age with proteinuria or neurological symptoms as tremor, action myoclonus, or seizures associated with storage material in the brain [9]. Mutations in SCARB2 (OMIM 602257) were found in three families with a single AMRF proband [5, 9]. However, analysis of patients with non-syndromic FSGS, MCNS, thin-basement membrane nephropathy, or non-Alport with hematuria and proteinuria did not reveal any mutations 
indicating a specific role of $S C A R B 2$ in AMRF [9]. $S C A R B 2$ encodes for the ubiquitously expressed lysosomal integral membrane protein type 2 (LIMP-2) mainly found in lysosomes and late endosomes [5]. This LIMP-2 protein has been shown to act as a receptor to bind $\beta$ glucocerebrosidase, the enzyme defective in Gaucher disease (lysosomal storage disorder) [105]. LIMP-2 deficient mice have also a kidney phenotype. The kidneys, which are non-hydronephrotic show pelvi-ureteric obstruction and glomerular lesions with mesangial hypercellularity and effacement of foot processes [9].

\section{Conclusion}

In the last years, knowledge of the genetic defects described above provided new insight in the structure and function of the podocyte slit membrane and the development of nephrotic syndrome. FSGS patients are a heterogeneous group with different underlying causes. Although the development of FSGS is not completely and solely explained by the presence of genetic abnormalities, the knowledge whether a FSGS patient carries a genetic defect turns out to be very important for determining treatment strategy and prognosis of the individual patient. For example, most of the patients with NPHS2 mutations are steroid-resistant and therefore treatment with steroids may be discontinued after obtaining the results of DNA analysis. Furthermore, in most cases, there is no recurrence of nephrotic syndrome after renal transplantation in patients with NPHS2 mutations. In patients carrying $W T 1$ mutations further medical examination and regular check-ups are required given the higher risk of developing malignancies. Mitochondrial DNA mutations may cause multi-systemic disorders requiring regular neurological follow-up and glycemia control. Finally, combined genetic defects in podocyte genes may play a role in the development of FSGS.

How to approach a patient with steroid-resistant nephrotic syndrome with FSGS in the biopsy? FSGS is not a specific histopathologic lesion. Similar alterations may be observed in a lot of other disorders [93] which should be excluded. When a hereditary disorder is suspected (a familial occurrence is not required) careful clinical and biochemical investigations could direct the research (neurologic symptoms, bone, eye, ear, genital abnormalities, thrombocytopenia). As the next step, the analysis can start with screening for the most frequent genetic disorders, taking the date of the first manifestation of the nephrotic syndrome in consideration. However, this frequency depends on the country of origin. It is not known for all genes. For NPHS2 an extensive evaluation was made by Berdeli et al. [15]. The incidence of podocin mutations in familial steroid-resistant nephrotic syndrome was found to be $29.2 \%$ in Turkey, being $40 \%$ in
European and American children, and $0 \%$ in Japanese and Korean children. The incidence of sporadic podocin mutations in Turkey (24\%) was similar to that in European and American children (10-30\%), but higher than in Chinese (4\%) and Japanese and Korean children (0\%). NPHS1 mutations are frequent in Finland. Two thirds of cases of nephrotic syndrome in the first year of life in a large European cohort are caused by mutations in four genes (NPSH1, NPSH2, WT1, and LAMB2) [42].

Further studies of the numerous podocyte genes coming from human and animal studies will undoubtfully identify new players on the edge of glomerular filtration barrier and will provide new insights into the pathogenesis of nephrotic syndromes in humans. The insight in the podocyte function obtained from the study of these genetic disorders will help to explain the effect of medication used in the treatment of glomerular disorders. Most drugs used in the treatment of nephrotic syndrome have a direct effect on the podocytes (corticoids [136], inhibitors of angiotensin-converting enzyme [45], COX2 inhibition [138], mizoribine [91], and cyclosporine [30]). The antiproteinuric effect of cyclosporine attributed to its immunosuppressive action, may also result from stabilization of the actin cytoskeleton in the podocyte. Cyclosporine protects synaptopodin from cathepsin 1-mediated degradation. Synaptopodin is an important regulator of podocyte function (see Fig. 2) [82]. Recent studies in the action of cyclosporine, frequently used in the treatment of FSGS [85], highlight this new concept [30].

Conflicts of interest The authors have no relationship with the organization that sponsored the research.

Open Access This article is distributed under the terms of the Creative Commons Attribution Noncommercial License which permits any noncommercial use, distribution, and reproduction in any medium, provided the original author(s) and source are credited.

\section{References}

1. Agarwal AK, Zhou XJ, Hall RK et al (2006) Focal segmental glomerulosclerosis in patients with mandibuloacral dysplasia owing to ZMPSTE24 deficiency. J Investig Med 54:208-13

2. Artero M, Biava C, Amend W et al (1992) Recurrent focal glomerulosclerosis: natural history and response to therapy. Am J Med 92:375-383

3. Artero ML, Sharma R, Savin VJ, Vincenti F (1994) Plasmapheresis reduces proteinuria and serum capacity to injure glomeruli in patients with recurrent focal glomerulosclerosis. Am J Kidney Dis 23:574-581

4. Ballermann BJ (2005) Glomerular endothelial cell differentiation. Kidney Int 67:1668-1671

5. Balreira A, Gaspar P, Caiola D et al (2008) A nonsense mutation in the LIMP-2 gene associated with progressive myoclonic epilepsy and nephrotic syndrome. Hum Mol Genet 17:2238-2243 
6. Barbaux S, Niaudet P, Gubler MC et al (1997) Donor splice-site mutations in WT1 are responsible for Frasier syndrome. Nat Genet 17:467-470

7. Barisoni L, Kopp JB (2003) Update in podocyte biology: putting one's best foot forward. Curr Opin Nephrol Hypertens 12:251258

8. Barker DF, Hostikka SL, Zhou J et al (1990) Identification of mutations in the COL4A5 collagen gene in Alport syndrome. Science 248:1224-1227

9. Berkovic SF, Dibbens LM, Oshlack A et al (2008) Array-based gene discovery with three unrelated subjects shows SCARB2/ LIMP-2 deficiency causes myoclonus epilepsy and glomerulosclerosis. Am J Hum Genet 82:673-684

10. Bertelli R, Ginevri F, Caridi G et al (2003) Recurrence of focal segmental glomerulosclerosis after renal transplantation in patients with mutations of podocin. Am J Kidney Dis 41:1314-1321

11. Boerkoel CF, Takashima H, John J et al (2002) Mutant chromatin remodeling protein SMARCAL1 causes Schimke immunoosseous dysplasia. Nat Genet 30:215-220

12. Bongers EM, Gubler MC, Knoers NV (2002) Nail-patella syndrome. Overview on clinical and molecular findings. Pediatr Nephrol 17:703-712

13. Boute N, Gribouval O, Roselli S et al (2000) NPHS2, encoding the glomerular protein podocin, is mutated in autosomal recessive steroid-resistant nephrotic syndrome. Nat Genet 24:349-354

14. Bruening W, Bardeesy N, Silverman BL et al (1992) Germline intronic and exonic mutations in the Wilms' tumour gene (WT1) affecting urogenital development. Nat Genet 1:144-148

15. Bwerdeli A, Mir S, Yavascan O et al (2007) NPSHS2 (podocin) mutations in Turkish children with idiopathic nephrotic syndrome. Pediatr Nephrol 22:2031-2040

16. Caridi G, Bertelli R, Scolari F (2004) Podocin mutations in sporadic focal-segmental glomerulosclerosis occurring in adulthood. Kidney Int 64:365

17. Caridi G, Perfumo F, Ghiggeri GM (2005) NPHS2 (Podocin) mutations in nephrotic syndrome. Clinical spectrum and fine mechanisms. Pediatr Res 57:54R-61R

18. Cheong HI, Chae JH, Kim JS et al (1999) Hereditary glomerulopathy associated with a mitochondrial tRNA(Leu) gene mutation. Pediatr Nephrol 13:477-480

19. Cormont M, Meton I, Mari M et al (2003) CD2AP/CMS regulates endosome morphology and traffic to the degradative pathway through its interaction with Rab4 and c-Cbl. Traffic 4:97-112

20. D'Agati V (2003) Pathologic classification of focal segmental glomerulosclerosis. Semin Nephrol 23:117-134

21. D'Agati VD (2008) The spectrum of focal segmental glomerulosclerosis: new insights. Curr Opin Nephrol Hypertens 17:271-281

22. D'Agati VD, Fogo AB, Bruijn JA, Jennette JC (2004) Pathologic classification of focal segmental glomerulosclerosis: a working proposal. Am J Kidney Dis 43:368-382

23. Dall'Amico R, Ghiggeri G, Carraro M et al (1999) Prediction and treatment of recurrent focal segmental glomerulosclerosis after renal transplantation in children. Am J Kidney Dis 34:1048-1055

24. Dandapani SV, Sugimoto H, Matthews BD et al (2007) Alphaactinin-4 is required for normal podocyte adhesion. J Biol Chem 282:467-477

25. Denamur E, Bocquet N, Mougenot B et al (1999) Mother-tochild transmitted WT1 splice-site mutation is responsible for distinct glomerular diseases. J Am Soc Nephrol 10:22192223

26. Diomedi-Camassei F, Di Giandomenico S, Santorelli FM et al (2007) COQ2 nephropathy: a newly described inherited mitochondriopathy with primary renal involvement. J Am Soc Nephrol 18:2773-2780
27. Doleris LM, Hill GS, Chedin P et al (2000) Focal segmental glomerulosclerosis associated with mitochondrial cytopathy. Kidney Int 58:1851-1858

28. Dustin ML, Olszowy MW, Holdorf AD et al (1998) A novel adaptor protein orchestrates receptor patterning and cytoskeletal polarity in T-cell contacts. Cell 94:667-677

29. Elizondo LI, Cho KS, Zhang W et al (2009) Schimke immunoosseous dysplasia: SMARCAL1 loss-of-function and phenotype correlation. J Med Genet 46:49-59

30. Faul C, Donelly M, Merscher-Gomez S et al (2008) The actin cytoskeleton of kidney podocytes is a direct target of the antiproteinuric effect of cyclosporine A. Nature Medicine 14:931-938

31. Freichel M, Vennekens R, Olausson J et al (2005) Functional role of TRPC proteins in native systems: implications from knockout and knock-down studies. J Physiol 567:59-66

32. Gbadegesin R, Hinkes BG, Hoskins BE et al (2008) Mutations in PLCE1 are a major cause of isolated diffuse mesangial sclerosis (IDMS). Nephrol Dial Transplant 23:1291-1297

33. Gessler M, Poustka A, Cavenee W et al (1990) Homozygous deletion in Wilms tumours of a zinc-finger gene identified by chromosome jumping. Nature 343:774-778

34. Ghiggeri GM, Caridi G, Magrini U et al (2003) Genetics, clinical and pathological features of glomerulonephritis associated with mutations of nonmuscle myosin IIA (Fechtner syndrome). Am J Kidney Dis 41:95-104

35. Goldenberg A, Ngoc LH, Thouret MC et al (2005) Respiratory chain deficiency presenting as congenital nephrotic syndrome. Pediatr Nephrol 20:465-469

36. Graham S, Ding M, Sours-Brothers S et al (2007) Downregulation of TRPC6 protein expression by high glucose, a possible mechanism for the impaired $\mathrm{Ca} 2+$ signaling in glomerular mesangial cells in diabetes. Am J Physiol Renal Physiol 293:F1381-F1390

37. Guery B, Choukroun G, Noel LH et al (2003) The spectrum of systemic involvement in adults presenting with renal lesion and mitochondrial tRNA (Leu) gene mutation. J Am Soc Nephrol 14:2099-2108

38. Haber DA, Buckler AJ, Glaser T et al (1990) An internal deletion within an $11 \mathrm{p} 13$ zinc finger gene contributes to the development of Wilms' tumor. Cell 61:1257-1269

39. Haber DA, Sohn RL, Buckler AJ (1991) Alternative splicing and genomic structure of the Wilms tumor gene WT1. Proc Natl Acad Sci U S A 88:9618-9622

40. Hasselbacher K, Wiggins RC, Matejas V et al (2006) Recessive missense mutations in LAMB2 expand the clinical spectrum of LAMB2-associated disorders. Kidney Int 70:1008-1012

41. Hattori M, Akioka Y, Chikamoto H et al (2008) Increase of integrin-linked kinase activity in cultured podocytes upon stimulation with plasma from patients with recurrent FSGS. Am J Transplant 8:1550-1556

42. Hinkes BG, Mucha B, Vlangos CN et al (2007) Nephrotic syndrome in the first year of life: two thirds of cases are caused by mutations in 4 genes (NPHS1, NPHS2, WT1 and LAMB2). Pediatrics 119:e907-919

43. Hinkes B, Wiggins RC, Gbadegesin R et al (2006) Positional cloning uncovers mutations in PLCE1 responsible for a nephrotic syndrome variant that may be reversible. Nat Genet 38:1397-1405

44. Hotta O, Inoue CN, Miyabayashi S (2001) Clinical and pathologic features of focal segmental glomerulosclerosis with mitochondrial tRNALeu(UUR) gene mutation. Kidney Int 59:1236-1243

45. Hsu HH, Hoffmann S, Endlich N et al (2007) Mechanism of angiotensin signaling on cytoskeleton of podocytes. J Mol Med 86:1379-1394 
46. Huber TB, Hartleben B, Kim J et al (2003) Nephrin and CD2AP associate with phosphoinositide 3-OH kinase and stimulate AKT-dependent signaling. Mol Cell Biol 23:49174928

47. Huber TB, Kottgen M, Schilling B et al (2001) Interaction with podocin facilitates nephrin signaling. J Biol Chem 276:4154341546

48. Huber TB, Kwoh C, Wu H et al (2006) Bigenic mouse models of focal segmental glomerulosclerosis involving pairwise interaction of CD2AP, Fyn, and synaptopodin. J Clin Invest 116:13371345

49. Huber TB, Simons M, Hartleben B et al (2003) Molecular basis of the functional podocin-nephrin complex: mutations in the NPHS2 gene disrupt nephrin targeting to lipid raft microdomains. Hum Mol Genet 12:3397-3405

50. Ilagan MX, Kopan R (2007) SnapShot: notch signaling pathway. Cell 128:1246

51. Jacob KN, Garg A (2006) Laminopathies: multisystem dystrophy syndromes. Mol Genet Metab 87:289-302

52. Jansen JJ, Maassen JA, van der Woude FJ et al (1997) Mutation in mitochondrial tRNA(Leu(UUR)) gene associated with progressive kidney disease. J Am Soc Nephrol 8:1118-1124

53. Jeanpierre C, Denamur E, Henry I et al (1998) Identification of constitutional WT1 mutations, in patients with isolated diffuse mesangial sclerosis, and analysis of genotype/phenotype correlations by use of a computerized mutation database. Am J Hum Genet 62:824-833

54. Jeansson M, Haraldsson B (2006) Morphological and functional evidence for an important role of the endothelial cell glycocalyx in the glomerular barrier. Am J Physiol Renal Physiol 290:F111116

55. Kaplan JM, Kim SH, North KN et al (2000) Mutations in ACTN4, encoding alpha-actinin-4, cause familial focal segmental glomerulosclerosis. Nat Genet 24:251-256

56. Karamatic Crew V, Poole J, Long S et al (2008) Two MER2negative individuals with the same novel CD151 mutation and evidence for clinical significance of anti-MER2. Transfusion 48:1912-1916

57. Karle SM, Uetz B, Ronner V et al (2002) Novel mutations in NPHS2 detected in both familial and sporadic steroid-resistant nephrotic syndrome. J Am Soc Nephrol 13:388-393

58. Kershaw DB, Sedman AB, Kelsch RC, Bunchman TE (1994) Recurrent focal segmental glomerulosclerosis in pediatric renal transplant recipients: successful treatment with oral cyclophosphamide. Clin Transplant 8:546-549

59. Kestila M, Lenkkeri U, Mannikko M et al (1998) Positionally cloned gene for a novel glomerular protein-nephrin is mutated in congenital nephrotic syndrome. Mol Cell 1:575-582

60. Kim JM, Wu H, Green G et al (2003) CD2-associated protein haplo-insufficiency is linked to glomerular disease susceptibility. Science 300:1298-1300

61. Kirsch KH, Georgescu MM, Ishimaru S, Hanafusa H (1999) CMS: an adapter molecule involved in cytoskeletal rearrangements. Proc Natl Acad Sci U S A 96:6211-6216

62. Klamt B, Koziell A, Poulat F et al (1998) Frasier syndrome is caused by defective alternative splicing of WT1 leading to an altered ratio of WT1 +/-KTS splice isoforms. Hum Mol Genet 7:709-714

63. Kobayashi S, Sawano A, Nojima Y et al (2004) The c-Cbl/ CD2AP complex regulates VEGF-induced endocytosis and degradation of Flt-1 (VEGFR-1). FASEB J 18:929-931

64. Kohsaka T, Tagawa M, Takekoshi $\mathrm{Y}$ et al (1999) Exon 9 mutations in the WT1 gene, without influencing KTS splice isoforms, are also responsible for Frasier syndrome. Hum Mutat $14: 466-470$
65. Kopp JB, Smith MW, Nelson GW et al (2008) MYH9 is a majoreffect risk gene for focal segmental glomerulosclerosis. Nat Genet 40:1175-1184

66. Kos CH, Le TC, Sinha S et al (2003) Mice deficient in alphaactinin-4 have severe glomerular disease. J Clin Invest 111:1683-1690

67. Koziell A, Grech V, Hussain S et al (2002) Genotype/phenotype correlations of NPHS1 and NPHS2 mutations in nephrotic syndrome advocate a functional inter-relationship in glomerular filtration. Hum Mol Genet 11:379-388

68. Kretzler M (2002) Regulation of adhesive interaction between podocytes and glomerular basement membrane. Microsc Res Tech 57:247-253

69. Kurogouchi F, Oguchi T, Mawatari E et al (1998) A case of mitochondrial cytopathy with a typical point mutation for MELAS, presenting with severe focal segmental glomerulosclerosis as main clinical manifestation. Am J Nephrol 18:551-556

70. Laakkonen H, Lönnqvist T, Uusimaa J et al (2006) Muscular dystonia and athetosis in six patients with congenital nephrotic syndrome of the Finnish type (NPHS1). Pediatr Nephrol 21:182 189

71. Lehtonen S, Zhao F, Lehtonen E (2002) CD2-associated protein directly interacts with the actin cytoskeleton. Am J Physiol Renal Physiol 283:F734-743

72. Levidiotis V, Power DA (2005) New insights into the molecular biology of the glomerular filtration barrier and associated disease. Nephrology (Carlton) 10:157-166

73. Little M, Holmes G, Bickmore W et al (1995) DNA binding capacity of the WT1 protein is abolished by Denys-Drash syndrome WT1 point mutations. Hum Mol Genet 4:351-358

74. Little M, Wells C (1997) A clinical overview of WT1 gene mutations. Hum Mutat 9:209-225

75. Liu XL, Done SC, Yan K et al (2004) Defective trafficking of nephrin missense mutants rescued by a chemical chaperone. J Am Soc Nephrol 15:1731-1738

76. Löwik M, Levtchenko E, Westra D et al (2008) Bigenic heterozygosity and the development of steroid-resistant focal segmental glomerulosclerosis. Nephrol Dial Transplant 23:31463151

77. Löwik MM, Groenen PJ, Pronk I et al (2007) Focal segmental glomerulosclerosis in a patient homozygous for a CD2AP mutation. Kidney Int 72:1198-1203

78. Lopez-Martin JM, Salviati L, Trevisson E et al (2007) Missense mutation of the COQ2 gene causes defects of bioenergetics and de novo pyrimidine synthesis. Hum Mol Genet 16:1091-1097

79. Lücke T, Franke D, Clewing JM et al (2006) Schimke versus non-Schimke chronic kidney disease: an anthropometric approach. Pediatrics 118:e400-407

80. Lynch DK, Winata SC, Lyons RJ et al (2003) A cortactin-CD2associated protein (CD2AP) complex provides a novel link between epidermal growth factor receptor endocytosis and the actin cytoskeleton. J Biol Chem 278:21805-21813

81. Marini M, Bruschi M, Pecci A et al (2006) Non-muscle myosin heavy chain IIA and IIB interact and co-localize in living cells: relevance for MYH9-related disease. Int J Mol Med 17:729-736

82. Mathieson PW (2008) Proteinuria and immunity - an overstated relationship? N Engl J Med 359:2492-2494

83. McTaggart SJ (2005) Childhood urinary conditions. Aust Fam Physician 34:937-941

84. McTaggart SJ, Algar E, Chow CW et al (2001) Clinical spectrum of Denys-Drash and Frasier syndrome. Pediatr Nephrol 16:335-339

85. Meyrier A (2005) Treatment of focal segmental glomerulosclerosis. Expert Opin Pharmacoth 6:1539-1549

86. Michaud JL, Lemieux LI, Dube M et al (2003) Focal and segmental glomerulosclerosis in mice with podocyte-specific 
expression of mutant alpha-actinin-4. J Am Soc Nephrol 14:12001211

87. Miner JH, Morello R, Andrews KL et al (2002) Transcriptional induction of slit diaphragm genes by $\mathrm{Lmxlb}$ is required in podocyte differentiation. J Clin Invest 109:1065-1072

88. Moller CC, Wei C, Altintas MM et al (2007) Induction of TRPC6 channel in acquired forms of proteinuric kidney disease. J Am Soc Nephrol 18:29-36

89. Montini G, Malaventura C, Salviati L (2008) Early coenzyme Q10 supplementation in primary coenzyme Q10 deficiency. N Engl J Med 358:2849-2850

90. Morrison AA, Viney RL, Saleem MA, Ladomery MR (2008) New insights into the function of the Wilms tumor suppressor gene WT1 in podocytes. Am J Physiol Renal Physiol 295:F12F17

91. Nakajo A, Khoshnoodi J, Takenaka H et al (2007) Mizoribine corrects defective nephrin biogenesis by restoring intracellular energy balance. J Am Soc Nephrol 18:2554-2564

92. Nakamura S, Yoshinari M, Doi Y et al (1999) Renal complications in patients with diabetes mellitus associated with an $A$ to $G$ mutation of mitochondrial DNA at the 3243 position of leucine tRNA. Diabetes Res Clin Pract 44:183-189

93. Niaudet $P$ (2004) Steroid-resistant idiopathic nephrotic syndrome in children. In: Niaudet P, Avner ED, Harmon WE (eds.) Pediatric Nephrology, Blackwell, Philadelphia, pp 557-573

94. Niranjan T, Bielesz B, Gruenwald A et al (2008) The Notch pathway in podocytes plays a role in the development of glomerular disease. Nat Med 14:290-298

95. Nishibori Y, Liu L, Hosoyamada M et al (2004) Disease-causing missense mutations in NPHS2 gene alter normal nephrin trafficking to the plasma membrane. Kidney Int 66:1755-1765

96. Orikasa M, Matsui K, Oite T, Shimizu F (1988) Massive proteinuria induced in rats by a single intravenous injection of a monoclonal antibody. J Immunol 141:807-814

97. Patrakka J, Ruotsalainen V, Reponen P et al (2002) Recurrence of nephrotic syndrome in kidney grafts of patients with congenital nephrotic syndrome of the Finnish type: role of nephrin. Transplantation 73:394-403

98. Pavenstädt H, Kriz W, Kretzler M (2003) Cell biology of the glomerular podocyte. Physiol Rev 83:253-307

99. Pelletier J, Bruening W, Kashtan CE et al (1991) Germline mutations in the Wilms' tumor suppressor gene are associated with abnormal urogenital development in Denys-Drash syndrome. Cell 67:437-447

100. Pereira AC, Pereira AB, Mota GF et al (2004) NPHS2 R229Q functional variant is associated with micro-albuminuria in the general population. Kidney Int 65:1026-1030

101. Philippe A, Nevo F, Esquivel EL, Reklaityte D et al (2008) Nephrin mutations can cause childhood-onset steroid-resistant nephrotic syndrome. J Am Soc Nephrol 19:1871-1878

102. Piechota J, Mroczek K, Bartnik E (2001) MELAS as an example of a mitochondrial disease. J Appl Genet 42:351-358

103. Putaala H, Soininen R, Kilpelainen P et al (2001) The murine nephrin gene is specifically expressed in kidney, brain and pancreas: inactivation of the gene leads to massive proteinuria and neonatal death. Hum Mol Genet 10:1-8

104. Quinzii C, Naini A, Salviati L et al (2006) A mutation in parahydroxybenzoate-polyprenyl transferase (COQ2) causes primary coenzyme Q10 deficiency. Am J Hum Genet 78:345-349

105. Reczek D, Schwake M, Schröder J et al (2007) LIMP-2 is a receptor for lysosomal mannose-6-phosphate-independent targeting of beta-glucocerebrosidase. Cell 131:770-783

106. Reiser J, Polu KR, Moller CC et al (2005) TRPC6 is a glomerular slit diaphragm-associated channel required for normal renal function. Nat Genet 37:739-744
107. Riccio A, Medhurst AD, Mattei C et al (2002) mRNA distribution analysis of human TRPC family in CNS and peripheral tissues. Brain Res Mol Brain Res 109:95-104

108. Rodewald R, Karnovsky MJ (1974) Porous substructure of the glomerular slit diaphragm in the rat and mouse. J Cell Biol 60:423-433

109. Roselli S, Gribouval O, Boute N et al (2002) Podocin localizes in the kidney to the slit diaphragm area. Am J Pathol 160:131-139

110. Roselli S, Heidet L, Sich M et al (2004) Early glomerular filtration defect and severe renal disease in podocin-deficient mice. Mol Cell Biol 24:550-560

111. Roselli S, Moutkine I, Gribouval O et al (2004) Plasma membrane targeting of podocin through the classical exocytic pathway: effect of NPHS2 mutations. Traffic 5:37-44

112. Ruf RG, Lichtenberger A, Karle SM et al (2004) Patients with mutations in NPHS2 (podocin) do not respond to standard steroid treatment of nephrotic syndrome. J Am Soc Nephrol 15:722-732

113. Sachs N, Kreft M, van den Bergh Weerman MA et al (2006) Kidney failure in mice lacking the tetraspanin CD151. J Cell Biol 175:33-39

114. Sartelet H, Pietrement C, Noel LH et al (2008) Collapsing glomerulopathy in Galloway-Mowat syndrome: a case report and review of the literature. Pathol Res Pract 204:401-406

115. Savin VJ, Sharma M, McCarthy ET et al (2008) Cardiotrophin like cytokine-1: candidate for the focal segmental sclerosis permeability factor. J Am Soc Nephrol 19:59A F-FC260

116. Savin VJ, Sharma R, Sharma M et al (1996) Circulating factor associated with increased glomerular permeability to albumin in recurrent focal segmental glomerulosclerosis. N Engl J Med 334:878-883

117. Scaglia F, Vogel H, Hawkins EP et al (2003) Novel homoplasmic mutation in the mitochondrial tRNATyr gene associated with atypical mitochondrial cytopathy presenting with focal segmental glomerulosclerosis. Am J Med Genet A 123:172-178

118. Schiffer M, Mundel P, Shaw AS, Böttinger EP (2004) A novel role for the adaptor molecule $\mathrm{CD} 2$-associated protein in transforming growth factor-beta-induced apoptosis. J Biol Chem 279:37004-37012

119. Schlöndorff JS, Pollak MR (2006) TRPC6 in glomerular health and disease: what we know and what we believe. Semin Cell Dev Biol 17:667-674

120. Schmiedel J, Jackson S, Schafer J, Reichmann H (2003) Mitochondrial cytopathies. J Neurol 250:267-277

121. Schwarz K, Simons M, Reiser J et al (2001) Podocin, a raftassociated component of the glomerular slit diaphragm interacts with CD2AP and nephrin. J Clin Invest 108:1621-1629

122. Sellin L, Huber TB, Gerke P et al (2003) NEPH1 defines a novel family of podocin interacting proteins. FASEB J 17:115-117

123. Seri M, Savino M, Bordo D et al (2002) Epstein syndrome: another renal disorder with mutations in the nonmuscle myosin heavy chain 9 gene. Hum Genet 110:182-186

124. Shih NY, Li J, Cotran R et al (2001) CD2AP localizes to the slit diaphragm and binds to nephrin via a novel C-terminal domain. Am J Pathol 159:2303-2308

125. Shih NY, Li J, Karpitskii V et al (1999) Congenital nephrotic syndrome in mice lacking CD2-associated protein. Science 286:312-315

126. Simons M, Schwarz K, Kriz W et al (2001) Involvement of lipid rafts in nephrin phosphorylation and organization of the glomerular slit diaphragm. Am J Pathol 159:1069-1077

127. Sours S, Du J, Chu S et al (2006) Expression of canonical transient receptor potential (TRPC) proteins in human glomerular mesangial cells. Am J Physiol Renal Physiol 290: F1507-F1515 
128. Srivastava T, Simon SD, Alon US (1999) High incidence of focal segmental glomerulosclerosis in nephrotic syndrome of childhood. Pediatr Nephrol 13:13-18

129. St John PL, Abrahamson DR (2001) Glomerular endothelial cells and podocytes jointly synthesize laminin-1 and -11 chains. Kidney Int 60:1037-1046

130. Taniike M, Fukushima H, Yanagihara I et al (1992) Mitochondrial tRNA(Ile) mutation in fatal cardiomyopathy. Biochem Biophys Res Commun 15:47-53

131. Thomas DB, Franceschini N, Hogan SL et al (2006) Clinical and pathologic characteristics of focal segmental glomerulosclerosis pathologic variants. Kidney Int 69:920-926

132. Tsukaguchi H, Sudhakar A, Le TC (2002) NPHS2 mutations in late-onset focal segmental glomerulosclerosis: R229Q is a common disease-associated allele. J Clin Invest 110:1659-1666

133. Verma R, Wharram B, Kovari I et al (2003) Fyn binds to and phosphorylates the kidney slit diaphragm component Nephrin. J Biol Chem 278:20716-20723

134. Vooijs M, Ong CT, Hadland B et al (2007) Mapping the consequence of Notch1 proteolysis in vivo with NIP-CRE. Development 134:535-544

135. Wagner KD, Wagner N, Schedl A (2003) The complex life of WT1. J Cell Sci 116:1653-1658

136. Wada T, Pippin JW, Nangaku M et al (2008) Dexamethasone's prosurvival benefits in podocytes require extracellular signalregulated kinase phosphorylation. Nephron Exp Nephrol 109:e8-e19

137. Wang SX, Ahola H, Palmen T et al (2001) Recurrence of nephrotic syndrome after transplantation in CNF is due to autoantibodies to nephrin. Exp Nephrol 9:327-331

138. Wang L, Flannery PJ, Rosenberg PB et al (2008) Gq-dependent signaling upregulates COX2 in glomerular podocytes. J Am Soc Nephrol 19:2108-2118
139. Weber S, Gribouval O, Esquivel EL et al (2004) NPHS2 mutation analysis shows genetic heterogeneity of steroid-resistant nephrotic syndrome and low post-transplant recurrence. Kidney Int 66:571-579

140. Weins A, Kenlan P, Herbert S et al (2005) Mutational and biological analysis of alpha-actinin-4 in focal segmental glomerulosclerosis. J Am Soc Nephrol 16:3694-3701

141. Weins A, Schlondorff J, Nakamura F et al (2007) Diseaseassociated mutant alpha-actinin-4 reveals a mechanism for regulating its F-actin-binding affinity. Proc Natl Acad Sci U S A 104:16080-16085

142. Winn MP, Conlon PJ, Lynn KL et al (2005) A mutation in the TRPC6 cation channel causes familial focal segmental glomerulosclerosis. Science 308:1801-1804

143. Woroniecki RP, Kopp JB (2007) Genetics of focal segmental glomerulosclerosis. Pediatr Nephrol 22:638-644

144. Yamagata K, Muro K, Usui J et al (2002) Mitochondrial DNA mutations in focal segmental glomerulosclerosis lesions. J Am Soc Nephrol 13:1816-1823

145. Yasukawa T, Suzuki T, Ueda T et al (2000) Modification defect at anticodon wobble nucleotide of mitochondrial tRNAs(Leu) (UUR) with pathogenic mutations of mitochondrial myopathy, encephalopathy, lactic acidosis, and stroke-like episodes. J Biol Chem 275:4251-4257

146. Zenker M, Aigner T, Wendler O et al (2004) Human laminin beta2 deficiency causes congenital nephrosis with mesangial sclerosis and distinct eye abnormalities. Hum Mol Genet 13:2625-2632

147. Zivičnjak M, Franke D, Zenker M et al (2009) SMARCAL1 mutations: a cause of prepubertal idiopathic steroid-resistant nephrotic syndrome. Pediatr Res 65:564-568

148. Nevo F, Machuca EA, Gribouval O et al. (2008) Abstract J Am Soc Nephrol 